\title{
Modernization and its Discontents: discourses on the transformation of caipira into sertanejo music'.
}

\author{
Elizete Ignácio dos Santos \\ Master and Doctoral Candidate at the Sociology and Anthropology \\ Graduate program of the Federal University at Rio de Janeiro
}

The purpose of this article is to understand the different ways to classify caipira and serteneja music and the relation of these classifications to discourses on the authenticity of one musical genre compared to another, from the point of view of Brazilian journalists Rosa Nepomuceno, João Luís Ferrete and Romildo Sant'Anna. ${ }^{2}$ These musical genres are rooted in the same rhythms and melodies, and are associated to rural life in Brazil. However, there has been a shift from the caipira to the serteneja genre that has coincided not only with the migration of rural populations to Brazil's large urban

1 This article is part of the first chapter of my master's dissertation, defended at the Sociology and Anthropology Graduate Program in the Federal University at Rio de Janeiro, entitled caipira and serteneja Music: classifications and discourses on the authenticity in the perspective of critics and artists. My thanks to professors: Maria Laura Cavalcanti, Santuza Naves and especially José Reginaldo Gonçalves for their support for this project. I would also like to thank professor Lucia Lippi for the opportunity to present this article at the II Pró-Arte Seminar at Cultural Heritage and Public Policy Working Group and professors Rogério Medeiros and Ligia Dabul, from The Sociology of Art Working Group of the Brazilian Sociological Society (SBS).

2 There are many books and newspaper and magazine articles - specialized or not - about the musical genres analyzed here. The works analyzed here were selected to compile a series of debates held in what could be called the "campus" (Bourdieu 1996) of caipira music. The book by Rosa Nepomuceno is based on the opinions of several agents who work in the field of caipira music. Said to be the "Bible" of caipira music, this book gave a chronological order to the debate about the authenticity of serteneja or modern serteneja music. The study, "A moda é viola: ensaio do cantar caipira" ("The Viola is In": an essay on caipira singing") is the post-doctoral thesis defended by Sant'Anna at Unesp. It was included because the author specifically analyzed caipira music, establishing a distinction from serteneja music. The authors' addressed issues of caipira music, that were only shallowly addressed by Nepomuceno. Finally, Ferrete's book is a monography that won the contest held by Funarte, Brazil's National Art Foundation. It is a biography of Ariovaldo Pires - Capitão Furtado -, considered to be the singer who introduced Latin genres to caipira music. Ferrete's book details the paradox stated in its title: "Capitão Furtado: “viola caipira” ou serteneja?” (Capitão Furtado: “Viola Caipira” or serteneja?), which refers to the difficulty in distinguishing, in practical terms, between the caipira and serteneja genres. 
centers throughout the $20^{\text {th }}$ century, but also with migrations within the rural environment itself. These transformations of the genres can be presented schematically as follows: ${ }^{3}$

\begin{tabular}{|c|c|c|c|c|c|c|c|}
\hline \multicolumn{1}{|c|}{ 19th Cent. } & $1930 / 1940$ & $1950 / 1960$ & $1970 / 1980$ & $1990 / 2000$ & $2010 .$. \\
\hline $\begin{array}{c}\text { Rural } \\
\text { Brazilian } \\
\text { Music }\end{array}$ & $\begin{array}{c}\text { Caipira } \\
\text { Music }\end{array}$ & $\begin{array}{c}\text { “serteneja” } \\
\text { Music }\end{array}$ & $\begin{array}{c}\text { Young } \\
\text { 'sertaneja' } \\
\text { Music }\end{array}$ & $\begin{array}{c}\text { Romantic } \\
\text { serteneja }\end{array}$ & $\begin{array}{c}\text { Modern } \\
\text { serteneja }\end{array}$ & $\begin{array}{c}\text { College } \\
\text { serteneja }\end{array}$ \\
\hline
\end{tabular}

The field of caipira music encompasses a wide range of individuals who claim to have a certain bond with a rural way of life, as opposed to an urban life. They include journalists, critics, record producers, singers in serteneja duos, composers, fans and admirers. They may listen to both caipira music - considered by many to be authentic rural music or the music of authentic rural people - and to serteneja music - considered by many to not be authentically rural. As in the development of rock music, each transformation in the genre is permeated by a sense of the "death" of the cultures that gave it origin or artistic form of expression (Freire Filho 2003). But some of the agents don't question the relationship between the loss of certain traits of caipira music and the appearance in serteneja music of new forms of symbolic adjustment in keeping with new media forms (Sahlins 1997).

In "Generos Rurais Urbanizados" ("Urbanized Rural Genres") (1974) Researcher José Ramos Tinhorão affirms that the "usage" of music genres of rural origin by urban composers began in the $19^{\text {th }}$ century and that migration to Rio de Janeiro, which was then the Brazilian capital, contributed to the development of serteneja music -the main distinguishing trait of which was that it was made by migrants from the Brazilian Northeast- and then became widely popular in the former Brazilian Capital. Tinhorão affirms that the records produced by Cornélio Pires ${ }^{4}$ would bring the "authentic" "caipira man"

3 This series does not deplete the technical forms and symbolisms that each sub-genre acquires in its own historical context. One must remark that the sub-genre "College Sertanejo" is a recent category that was analyzed in this article.

4 Born in the São Paulo state countryside in 1884, Cornélio Pires was a writer, songwriter, singer and musical producer. Until the end of the 1920 his songs were sung by urban singers who would present themselves wearing clothes and mimicking the manners of "caipiras" from the interior of Sao Paulo and Minas Gerais. Cornélio Pires made an unprecedented independent production of a compilation of "caipiras" born in the São Paulo countryside, and issued 25,00o copies - a great sales success for the time. Soon other issues followed, encouraging the Brazilian record industry to invest more in rural artists. For more about the life and work of Cornélio Pires, see Nepomuceno (1999) or http://www.dicionariompb.com.br/cornelio-pires. 
to the urban scene. In a more recent article, Tinhorão explains in another way the difference between caipira and serteneja music. He says that they were born differently in the sense that they are icons to populations from different parts of Brazil. In his book "Música sertaneja é esse negócio" (Serteneja music: that's the deal) (2001), he states that caipira music is associated with a geographic region where the sound of the "viola" (a kind of hillbilly guitar not related to the homonymous classical instrument) is predominant. Tinhorão maintains that recently recorded serteneja music represents a "consumer product" for populations who identify with their rural origin.

This understanding of serteneja music as a consumer product for migrants from rural areas is echoed by academic works such as those of José de Souza Martins (1975) and Waldenyr Caldas (1979). In "Música serteneja: a dissimulação na linguagem dos humilhados" ("Sertaneja' Music: dissimulation in the language of the humiliated"), Martins demonstrates that caipira and serteneja music are not equal genres. Caipira music is inseparable from its ritual context, whether religious or profane - - as in the songs called "modas caipiras" [caipira style songs] for work or leisure, according to Martins. From this point of view, caipira music is mainly "functional" since it is embedded in a daily caipira way of life. Seen as a means and not as an end, it has use value more than exchange value, which is not the case of serteneja music. Martins affirms that serteneja music is embedded in the cultural industry, which is in opposition to the rustic culture that is the matrix of caipira music. The audiences of these genres are different because the "consumers" of caipira music are the producers themselves - rural inhabitants and workers - while the audience for serteneja music is those who migrated from the rural areas to the urban centers and their descendants.

In Acorde na aurora [The title is a play on words that could mean A Chord in the Dawn or Wake up at Dawn] (1979), Caldas takes up the line of study begun by Martins. Considering caipira music to be undeniably linked to the context of its rural production and to the folklore of the countryside in São Paulo State, his objective is to analyze "the ideological meaning of serteneja music. For the author, after an urban development process, serteneja music began to play a useful role and to become particularly widespread in the urban centers of Brazil's South, Southeast and Midwestern regions. This led to an "intensification of the alienation inherent" to the lower strata of the population. He also states that from an esthetic perspective, serteneja 
music cannot be considered art, given the "esthetic redundancy" of its form and content - as in the abusive use of similar tunes and its mimicry of other genres. To summarize, he believes that serteneja music is simply another instrument to support bourgeois ideology, rather than a sincere "expression" of its producers and consumers. It is here where Caldas and Martins disagree. For the latter, although serteneja music has become an urbanized genre, it reflects the perspective of the caipira man humiliated in the city. For Martins, the positive aspect of serteneja music lies in the fact that the lyrics protest against the dire living conditions that rural migrants find in the urban center, while it reinforces an "ideological idea" that the dominant classes have of the "caipira."

The analyses of Tinhorão, Martins and Caldas are a response to a process of transformation that took place in the field of caipira music and which led to a new classification of it as serteneja music. This is described by Nepomuceno as an emergence of an "unsurpassable abyss" between the two genres, which is expressed in terms of an antinomy between an "authentic" caipira music and a "not authentic" sertaneja music. The transformations are perceived neither as a process of individual refining nor as a cultural remake. To the contrary, her analyses emphasize a discourse on the loss of authenticity.

The ballads and "rancheiras" with pop arrangements and sung in intervals of thirds by "Chitãozinho e Xororó" created an unsurpassable abyss between two worlds - the one of traditional music and that of modern serteneja, which was now given its most refined form. It was at that time that purists invented unfriendly adjectives to define them, like "sertanojos"s (Nepomuceno 1999: 198)

In Música caipira: da roça ao rodeio ('Caipira' music, from the field to the rodeo) (1999) Nepomuceno describe the history of this genre from its "discovery" by the media in the 1920s, until the arrival of the large rodeos, like those held every year in the city of Barretos in Sao Paulo State. The author, in addition to presenting a history of caipira music, presents statements and opinions of many viola players, singers, songwriters, record producers and TV

5 In Brazilian Portuguese the word "nojo" means nausea. So, "sertanojo" would be a disgusting sertanejo music. 
broadcasters, who she refers to as "protagonists" in this history. ${ }^{6}$ By bringing these voices to her book - which, although they are polyphonic, all perceive this "unsurpassable abyss" between the caipira and the modern serteneja genres - she reconstructs a history that, page after page, strengthens the image of this abyss by affirming an opposition between "authentic" caipira, and its "roots", and "inauthentic" "modern" serteneja music.7

The understanding Nepomuceno has of the roots of caipira music resembles the position of João Luís Ferrete in his book "Capitão Furtado: viola caipira ou serteneja (Capitão Furtado: viola caipira or serteneja”) (1985). In writing the biography of songwriter Ariovaldo Pires ${ }^{8}$ - or "Capitão Furtado" - the author found a need to retell the history of "rural music", which he considers the music that has accompanied the development of humanity since the early days of its existence. Therefore he looks at the history of ancient civilizations to demonstrate that not only caipira music, but all music, has a rural origin. According to Ferrete, rural music was the first to be known in the world and humans are more rural than urban beings. For Ferrete, both the industrial revolution and the appearance of big cities result from life in the countryside. He emphasizes:

[The] line of thought will remain entirely turned to the genesis of a new type of popular music manifestation, an itinerary that (...) has its roots in the most ancient civilizations, in an attempt to demonstrate the rural origins of the first spontaneous elaborations [of Man] (...) (Ferrete 1985: 18).

By telling the history of caipira music with a "focus on the genesis of a type of popular manifestation", Ferrete affirms he takes an ethnographic approach to the theme as he analyzes the caipira way of life and its influence on

6 Throughout this work, these "protagonists" are less focused than the author herself, but are nevertheless an important part of her account of caipira music.

7 In this work, the supposed "authenticity" of caipira music is observed as a construction based on the account of the three critics analyzed and not as something truly inherent to this musical genre. Many authors have debated the problem of the search for "authentic culture". See especially Benjamim (1980), Gonçalves (1988, 1996) Sapir (1949) and Trilling (1972).

8 Singer and songwriter Ariovaldo Pires - or Capitão Furtado - was Cornélio Pires' nephew. His songs were highly successful throughout the 1950 and 1960 . He is said to be the first caipira artist to "mix" the caipira genre of the Sao Paulo hinterland to the Latin rhythms of the Brazilian States that border other Latin American countries, especially those to the south (Argentina, Uruguay, Paraguay and Bolivia), to where he would often travel to perform. To learn more about Ariovaldo Pires, refer to the biography analyzed here, by J. L. Ferrete, or even http://www.dicionariompb.com.br/capitao-furtado. 
urban man, rather than establishing a descriptive and historical relation with rural music. It is through this lens that he portrays the rural world as the space that gave origin to mankind and its culture, and that which makes the human an authentic human being. Rural and urban are thus not dichotomic realms, but actually hierarchical and complementary. "Urban" is a later moment of mankind and a consequence of that which is rural.

Like Ferrete - and in opposition to Nepomuceno, who makes an effort to make a descriptive historical account and one based on the biographies of "viola" players, singers, musicians and other people in the field of caipira music - communications scientist Romildo Sant'Anna analyzes culture and civilization. From his point of view, the category "roots" refers to immemorial and a-historical times and is revealed by means of the creativity and spontaneity of the caipira [rural man], who can only be found in his or her own context and which Sant'Anna affirms is primitive and original. In his postdoctoral thesis, A moda é viola: ensaio do cantar caipira ("Viola is in: an essay on 'caipira' singing") (2000), the author bases his studies on the understanding of a genre which he calls "moda caipira' roots" or "literature founded in the distant past". He defines "roots", as that which "has to do with a real, active and natural participation in the existence of a collectivity that maintains certain treasures of the past and a certain intuition of the future" (Weil, apud Sant'Anna, p. 19-20). Thus, he affirms that the concept of roots implies the need to understand the life of the caipira as something complete or integral in time and space. "Moda caipira" roots makes this completeness effective, although it is understandable only within its own context. Thus both recorded "toadas" [typical caipira tunes] and "modas viola" [instrumental styles] as well caipira shows would be "simulacrums" of caipira rites and sociability, appearing as unfaithful reproductions that seek to assure - although they do not succeed - the aura of the songs (Sant'Anna 2000: 20).

By establishing a qualitative difference between the "moda "caipira roots' and the "phonographically recorded "moda caipira", the author differentiates urban from rural and inauthentic from authentic, a difference that he claims has deepened since the 1930s. Most of all, he intends to

9 In Brazilian Portuguese it known as "literature of long provenance".

10 "Toadas" and "Moda de violas" are songs based on oral narratives that speak about the context of their composers. Their lyrics are written in verse and the musical accompaniment is made by only one instrument, the viola. 
recreate a social context of cultural production that he believes has been lost. His interest is less in the deepening of this differentiation than in the apprehension of what he considers to be the primitive and original context of caipira music: its production by what would be "authentic caipiras", born on farms or in small rural towns in Minas Gerais and Sao Paulo States. In the last two chapters of his book, Sant'Anna remarks that "modern sertaneja music" is totally different from caipira music, since it does not come from this social-cultural context.

Thus, with more or less intensity, all three authors emphasize a classificatory system of mutually exclusive and opposite pairs, without noticing the several ways in which they contribute to creating this abyss that is built at the level of their critical discourse, especially when presenting testimonies about the caipira way of life, as well as authors. Rosa Nepomuceno states:

... [I] began to write the book in the house at General Teles Street [Botucatu] where I spent my childhood and adolescence with my brothers... With my father playing the guitar, grandfather playing violin, and mother singing... when Tarik made me the invitation, I rediscovered the girl from Botucatu in a Rio de Janeiro disguise, with a small array of memories typical of the Sao Paulo State countryside (Nepomuceno 1999: 11).

\section{In avid times: authenticities and roots in narratives about caipira music}

Although it is not an autobiography, the author sees the book as a rediscovery of her own self, and the process summoned memories that guided her writing. Like Nepomuceno, Ferrete and Sant'Anna also begin their books by emphasizing their rural roots, presenting themselves as "witnesses" to the history that they narrate and analyze. Thus, while all three books offer a personal and authentic dimension, they all focus on a distant past from many years before each of them was born. They present a time they did not experience, but learned about through their research, as something of extraordinary value.

Nepomuceno divides her book into two parts: in the first one, significantly called "The history", she not only sketches a chronological order, but also presents a few of the themes present when distinguishing caipira music from others. In the second part, called "The protagonists", Nepomuceno speaks a bit 
longer about sixteen duets or artists, dedicating a chapter to each of them. Both parts complement each another by demonstrating phases of a rise and fall in caipira and serteneja music. She concludes with a chapter on the duo "Chitãozinho e Xororó", the sole representatives of "sertanojo" in the book. In opposition to modern serteneja another group appears in the book, called "new caipiras": young viola players, usually born in big cities, who learn to play the viola and use it to play a type of chamber music. The author claims that this group has been responsible for a rebirth of caipira music since the 199o's and emphasizes that its representatives took paths opposite than the modern sertanejos: born in the cities, they turned to the countryside in search of their roots.

The duet ["Lourenço e Lourival"], which had previously recorded serteneja roots - a term that began to be used to refer to traditional rural genres -, was now given [on a record of 1968] a new profile for their "modas de viola"... they inaugurated a new and more sensual language to talk about love, exchanging the kisses of the shy country girl under the trees for the love of sensual young women in motel rooms... it was the shipwreck of discrete rural life (Nepomuceno 1999: 168-169).

The designation roots music and the idea of roots itself both come to establish an opposition between the more traditional genres and the "new profile" of "moda de viola" duos such as "Lourenço e Lourival". On their 1968 record, caipira music is arranged for instruments such as electric guitar and drums and the songs - which in Nepomuceno's view were until then more naive - begin to address personal and romantic relations in a more direct and provocative manner, without what she considers to be the subtleness of the caipira perspective. The designations "roots music" and "roots" are continuously used throughout the book, both by the author and by her "protagonists" and its absence is presented as the main argument against "modern sertanejo", without a concern to formally define them.

However, it is possible to see how Nepomuceno regards those roots of caipira music: linking them to the Brazilian modernist ideal of a return to tradition and adherence to nationalism and to the ideals of German romanticism in its search for a popular and genuine art. ${ }^{11}$ Therefore modern sertanejos,

11 To follow the discussion on Brazilian modernism, refer to Moraes (1999) and Naves (1998). Isaiah 
by letting go of their "roots," also cease to value what is "true" or "genuinely" national and which has its origins in the arrival of the Portuguese to Brazil and their mixing with blacks and indigenous peoples. Her reflection focuses on the adoption by the modern serteneja duets of rhythms and instruments - mainly those influenced by U.S. country music - that are foreign to caipira music, which should represent a rural, bucolic, romantic, rudimentary and mystical Brazil (Nepomuceno 1999: 18). These are adjectives that could be used to describe her definition of caipira.

For Sant'Anna, the caipira songbook is part of Brazilian popular literature and an heir to European Medieval literature or, in his definition, popular literature from a remote time, having its origins in medieval troubadours. Part of his book is dedicated to comparisons between medieval poems and "modas" ${ }^{12}$ or caipira songs recorded in Brazil since the 1920s. When emphasizing the remote roots of "moda caipira", Sant'Anna seeks to demonstrate that these roots were brought here by the Portuguese colonizers and continue to expand because of racial mixing, stating that the "roots" of Brazilian culture are best expressed "through a sense of rusticity, spontaneity, a condition rather naïve, fauvist, when challenged by the esthetic principles of the Old World..." (Sant'Anna 2000: 76, italic font of mine). "Moda caipira" is approached mainly as marginal literary texts - and not as song - that needs to be removed from this condition. ${ }^{13}$ Even when referring to it as a kind of musical poetry, Sant'Anna emphasizes the literary traits of the text, not considering the formal technical aspects of the songs analyzed ${ }^{14}$.

The realm of what is "emotional", "irrational' and "mystical" would

Berlin (2000) discusses the romanticism of Herder and the Enlightenment. Stocking Jr. (1989) initiates a discussion on the influence of romanticism in North-American anthropology in the early $20^{\text {th }}$ Century. On the relation between Brazilian modernism and German romanticism, see Travassos (1997) and Cavalcanti (2004).

12 Here one must remark that Sant'Anna's approach to roots "Moda Caipira" encompasses a large number of rural Brazilian musical styles such as "cateretê", "lundu" and "moda de viola" itself, and excludes the serteneja rhythms that have appeared since the 196os. An observation of his analyses, reveals that "moda caipira" is any caipira song that has ties to medieval poetry, especially "toadas", "cateretês" and "modas-de-viola".

13 In general, caipira music critics and producers tend to see it as folk music. Without wanting to analyze the question of qualifying folk music and songs, I consider caipira music as something that is not limited solely to its production context, given that since the 193os it has been recorded and important to the record industry. For a deeper discussion of this theme, see Sandroni (2001).

14 This reflects the approach to "música caipira" as folk and not as popular Brazilian music. 
be the basis of a popular Brazilian set of songs, lyrics and poetry" resulting from the miscegenation of the African, Indigenous and Portuguese peoples, to the extent that caipira themes stress these typical traits of mestizo peoples. This feeling would be the cement for a mestizo national art that, due to the troubles of colonization, expresses the qualities of survival and permanence. This is how "moda caipira" is simultaneously an icon and a metaphor for the survival of national culture within the modern recording industry.

Considering roots "moda caipira" as an icon of Brazilian art, Sant'Anna formulates an understanding of colonization, for which he holds both the Portuguese and Spanish accountable and thus refers to Brazil's Iberian colonization throughout the book. The contribution to miscegenation is not limited to the Portuguese, Spanish, black and indigenous peoples, but also to Italians, the Dutch and the French. He qualifies the different contributions of each racial element to roots "moda caipira" as follows:

...It is white in its forms and rhymes, and a fabric of indigenous, black and white thought and emotion. Through the viola and its singers, it expresses the bitterness of Brazil's cultural shades [sic]; the melancholic and exiled Portuguese, the migrated Indian and African slaves, mortified by physical and moral impoverishment... (Sant'Anna, p. 93). [sic from the original]

In this regard, Sant'Anna disagrees with other journalists who see the Portuguese as the central founding element of a caipira way of life. According to Ferrete, Brazilian rural music originates from the miscegenation of Portuguese colonizers with indigenous Brazilians. He affirms that the contribution of black people would be smaller compared to these two elements. One can assume that when coming to this new land, the Negroes would have already found echoes of an emerging civilization. The author disagrees with the common view that depicts the Portuguese merely as colonizers. According to Ferrete, in addition to their intention to exploit the newly discovered lands, the Portuguese also wanted to populate it. Population and exploitation were joint needs that governed the Portuguese, given the "poor" resources offered by the land, "except for brazilwood, used for dyeing", in the first two centuries of Portuguese presence.

Sant'Anna and Ferrete also differ about this issue. For the first, it was the careless quest for riches and spices found in the new land, rather than 
the intention to populate it that led to the ethnic contact that gave birth to the caipira way of life.

... This invading and adventurer rabble [the Portuguese] had no other objective - since they would not find the coveted spice of the Indies - than to look around with eager eyes for a lump of gold, a trunk of brazilwood or any other good that would allow them to enrich and adorn suitcases, pockets and bags. At the same time, there they were, on terra firma: a little harmonica and tambourine to liven the village celebrations, to alleviate homesickness, having them dance without adornments, without rules or any boundary as if something new was being born, or even something as ancient as the myth of primeval freedom was taking place... (Sant'Anna 2000: 70).

It is in the São Paulo "bandeirante" (pioneer) that Nepomuceno sees the direct heritage of the Portuguese explorers. While she gives credit to miscegenation for the roots of caipira music, it is the pioneering spirit that she affirms is responsible for the expansion, strengthening and permanence of the genre. It would be the pioneering, explorative, and seed sowing "spirit" of the Portuguese that gave origin to the "bandeirantes" "15 mule teams, cowboys and even the modern rodeo riders. The explorer - whether the Portuguese colonizer or the Sao Paulo "bandeirante"- is the ancestor of the caipira, and is described by Nepomuceno as the protagonist of a mythical time of colonization. He is the root of caipira music and responsible for its resistance and permanence.

This description of caipira music gives most of the credit to Portuguese influence ${ }^{16}$ as the founder - or that which made the manifestation possible of Brazilian culture. While the native Indians and the black influence are not ignored, their contribution is seen to have only been possible given the trail blazing, colonizing and populating role played by the Portuguese. However, the over valuation of the Portuguese element in the history of caipira music is not based on racist theories that try to prove the superiority of the white man compared to black or indigenous elements, but on the perception of the

\footnotetext{
15 "Bandeirantes" were men who made exploratory expeditions to interior regions of Brazil in the nineteenth century.

16 According to Roberto DaMatta (1984), it is possible to see the Portuguese not as an empiric subject, but as a discourse resource, which justifies for some critics the foundation of the "Brazilian nation" and of national "musicality".
} 
mediating and heroic role played by the Portuguese. Yet, this heroic trait of the Portuguese does not free them from being guilty of instilling a process that was painful to the indigenous and the blacks. Sant'Anna removes from his analyses the figure of the "bandeirante" and large latifundistas related to abusive economic systems that do not combine with the image of the kind and simple caipira, someone belonging to a lower layer of the Brazilian social pyramid. The caipira as the fruit of miscegenation is not considered in terms of his contribution as a "race", but as the "real Brazilian", the cultural and social inheritor of the pain of the Negros, the indigenous and, why not, of the Portuguese themselves.

If for Nepomuceno the expression "roots sertanejo" came to identify "traditional" rural genres, in opposition to new styles of romantic serteneja, the roots category is also used to identify other musical genres like samba and "forró". The expression mainly emphasizes the supremacy of what is old, from the past and authentic in relation to what is new, modern and inauthentic. The notion of roots allows understanding that the opposition between caipira and modern serteneja music is not restricted to an antinomy but reveals a search for a lost authenticity. Thus roots would be everything having an aura of history, which is the basis for the notion of authenticity (Benjamin, 1980). However, it is not an immemorial past and one marked by colonization. For this reason the myth of the three races has a special place in the views of the critics of romantic serteneja music, since the reconstruction of the myth allows bringing this search to an end. In the myth of the three races - these races form the roots of caipira music - the caipira authenticity is thus re-established while modern serteneja music is accused of abandoning these roots ${ }^{17}$ and its own history.

17 In "O discurso crítico brasileiro" ("The Brazilian critical discourse"), Maria Eneida de Souza identifies six metaphors present in the imagery of cultural criticism about transculturation (which discusses the relations between universalism and national identity, modernization and a socially homogenizing political project, as well as the constitution of counterculture discourses in marginalized and dependent neo-colonial societies" (Souza 2002: 47)). In the accounts of critics on the caipira and serteneja genres, I find it especially remarkable how the terms economic and organic are used as metaphors. Thus, in Brazilian critical discourse, the "dialectic identity of Brazilian culture" would be "condemned to fluctuate between being local and universal, the same and the other, civilization and primitivism, 
Even though at the poorest level, or precisely because of it, the roots caipira "moda" never becomes anachronistic: it brings with it the timelessness and the bonds with codes and symbols of the elemental orchestrations of existence, casually carved by time... (Sant'Anna 2000: 239).

Even when admitting that social acts in general have the consistency of permanence, in the rural realm, references become more endurable by clinging to the essential roots of tradition. The writer of "modas caipira" moves according to predictable bases that have as pillars the cultural acts of his context, with his feet on the present and his eyes in the past (Sant'Anna 2000: p. 112).

caipira or rural music seems to have been born with an ability to remain immutable. In other words: it is forever a child (Ferrete 1985: 121)

In these reconstructions of caipira music history, the present and the past are articulated in such a way that its permanence and durability makes it nearly immutable and assured by tradition and by its inherent timeless nature. Sant'Anna ends his narrative in the 1980 os and emphasizes that his analyses address a roots "moda caipira" that is previous to the recording industry that began in the 1920s. Actually, as said before, he considers the recordings of caipira songs as simulacrums of the roots "moda caipira". Nepomuceno views several elements of what is considered caipira music with suspicion and as being responsible for a loss of authenticity. Ironically, new terms arise to qualify what is older and differentiate them from what is modern. In turn, Ferrete sees caipira music as immutable throughout time and any change given the arrival of the recording industry, radio and then TV - could only be based on its mixture with other genres. It is as if caipira music would not be able to change when left to its own devices.

Less than a decade after its discovery... the "confrontation of destinies" was having revenge, the miscegenation of the old culture was born, in avid and

modern and archaic." (Souza 2002: 51). In "A canção crítica" ("The critical song”) Santuza Naves (2001) discusses the values surrounding critical activity related to popular music that increasingly come to use anthropological criteria - linking values and meanings related to the production contexts - rather than to vanguard concepts of technical refinement and innovation - which focus on analyzing the form. Ferrete, Nepomuceno and Sant'Anna all base their reflections on economic metaphors- in the sense that they emphasize the gains and losses resulting from colonization - and organic metaphors - seen as natural elemenst related to the idea of roots, which is translated into culture - as well as overlapping the anthropologic criteria for the technical aspects of caipira and serteneja music. 
mercantile times, with ethnicities and modes of life in a state of grace, marked by the primary nature of the American Indian and African anthropological relations, the primary trait of "a good people and a beautiful simplicity", as observed by Pero Vaz de Caminha (Sant'Anna 2000: 71, quotation marks mine).

If the memory and the time lived in by the authors are witnesses to changes to caipira music, which led to its separation from serteneja music, this reconstitution of history is the reconstitution of the "authentic" context for making caipira music. In other words, since the past of caipira music is not associated to memory but to a supposed antiquity, everything can be accepted that, in terms of narration, presents itself within this mythic original time.

The re-built historical past is characterized by being integral, while the present is characterized by fragmentation. This is why timelessness and immutability do not imply a simple freezing: it is not as if things simply have not changed. To summarize, changes in caipira music must not reflect the way of life of a modern and fragmented present, yet an idealized mythical time. Caipira music is barely conceivable outside of this time that gave it origin. This is why the figures of the Portuguese, of the mixed blood "caboclo" and of the trail blazing "bandeirante" are emphasized, because authenticity is seen as found in an integrity that is both historical - seen through a continuous succession of such characters - and spatial - sewn together by the figure of the "bandeirante" who "pioneers" the hinterland.

Our art is born with a vocation for being primary, sensual, due to the hegemony, at the roots of a special crossing of autochthone strata over peninsular cultural shades which, theoretically, could colonize them by force. [...] It is from this substrate [changes at cultural levels] and the fusion of the raw and cooked stews (as Levi Strauss would say), and considering the transformations in process given the geographic conditions, of the internal migratory demands and of the foreign immigrations, that a cultural genre was born: the caipira and its expressive domains (Sant'Anna 2000: 76-78)

From Sant'Anna's viewpoint, two equivalent categories address what would be the caipira way of life: "caipirism" and primitivism. "Caipirism" refers to the integral way of life of the inhabitant of the rural areas of Brazil's Southeast, South and Midwest, resulting from the special cross-matching of native strata". Primitivism refers to a set of traits belonging to the field of the uncivilized which are still present in “caipirism”. While Sant'Anna uses 
these categories widely, they are also echoed in Nepomuceno and Ferrete. According to these authors, caipirism is an expression of what is primitive, naive. This concept relates to the myth of a freedom of living evoked by Sant'Anna; which is the same as creative freedom, as the absence of rules from the Portuguese crown over its Brazilian subjects. An "Iberian passion" is one of the traits that distinguish the caipira way of life and the music which is supposedly its form of artistic expression. This passion, this sensuality, this nostalgia and this simplicity are considered feelings experienced by the Portuguese, the indigenous and the blacks - a longing - and are recognized by Sant'Anna as a syndrome of a longing for the pastoral. He affirms that it is for this reason that the "moda caipira" has a "nostalgic, melancholic and passionate" trait. [Since] it reflects the feelings of the people, encouraging them to use their imagination" (Sant'Anna 2000: 93).

The idea of a primitive and integral life strengthens among the authors the perception that caipira art or music can only be conceived within its ritual context, which includes moments of leisure - to the extent that in rural regions art, religious expression and fun are all part of a single ritual. Thus, Sant'Anna's radical perception is that roots "moda caipira” is almost exclusively produced at and limited to rural festivals. He maintains it is the fruit of collective creation, in which the audience is "a participant who productively intervenes and has an influence as a modeler and provides feedback full of creative energy." This creation takes place within ritual contexts such as "the Day of Kings celebration, the Saint Gonzalo festival, and the festival of the Divine Holy Spirit (Sant'Anna 2000: 17). According to Ferrete, caipira music always emphasizes the uniqueness of the caipira, a rural person molded by trail blazing adventures and defined in the interior of Sao Paulo. ${ }^{18}$ To summarize, the roots are planted in a mythical time which defines the authenticity of caipira music and its main trait lies in a way of life seen as integral ${ }^{19}$ - and

18 In his careful description of the way of life of the inhabitants of Bofete, Antônio Cândido (2001) unintentionally inaugurates a new perspective on the caipira way of life, based on the totality of relations within the rural region. In the works analyzed here, the authors recur to images sketched by Cândido to "offer authenticity" to their analyses. The definition of caipira music as one that is ritualized within a context comes from the works of José de Souza Martins and Waldenyr Caldas. As part of the rural world, the displacement of caipira music would necessarily result in a loss of its traits. serteneja music, on the contrary, is directly linked to urban life, an "imitation" of rural life in the big cities, created to fulfill a need for leisure and fun of a new audience: workers who have migrated from rural areas, and their children and grandchildren.

19 Here it is possible to take up the discussion by Edward Sapir (1949) about authentic culture and 
which is summarized simply as "caipirism" -, where all elements are inseparable from each other.

\section{"The order, now, is to be modern": the transformation of caipira music into serteneja music}

The attitude of 'wanting to be modern' by rejecting what is of the people is in dissonance with the sense of modernity itself, which, in Brazil, gained strength among the ranks of writers and intellectuals from the generation of the 1930s (Sant'Anna 2000: 335).

But who, in this web-surfer life, wants to be a modernist? It is now mandatory to be modern, to be multi, international and to master languages (Nepomuceno 1999: 24).

The costume of the singers adopts the same traits as the so called urban ones, the "moda" viola is played by all kinds of instruments except for the viola itself, and the typical tunes would gradually make room for the "Mexicanizations" or Paraguaisms", making clear that a cultural adaptation to what is commercial is taking place. Electric guitars were even introduced, justified as a "modernization" or "adaptation to a new reality" (Ferrete 1985: 70)

The above quotes express "discontent" with the mixture ${ }^{20}$ in serteneja music of rhythms and instruments considered typically caipira with foreign rhythms and instruments, which began in the second half of the $20^{\text {th }}$ century. This mixture involves the fusion of different rhythms; the composition and recording of different styles by a singer-songwriter; or even the introduction

spurious culture, because from the perspective of critics of modern serteneja, its proponents abandon their cultural legacy by choosing a more financially profitable path. However, considering the field work I did with viola players and modern serteneja artists in Alto Belo (northern Minas Gerais), it was possible to observe that, on one hand, the modern serteneja duets work with values more linked to vanguard criteria of artistic elaboration and, on the other hand, regard both the inherited tradition (acknowledged as a gift) and the direct relation to the public - to whom are directed the values linked to technical refinement and modernization - to be the base of their work as singers and songwriters (Santos, 2005).

20 Mixture ( mistura in Port.) is a native category widely used by caipira music critics. Given the understanding of mixture, it is clear that foreign is everything not acknowledged as belonging to the field of caipira music. 
of instruments considered foreign (like the samba percussion instrument called the cuíca or the use of the caipira viola in samba). This mixture is understood by producers, songwriters, musicians and serteneja and caipira duets as modernization. However, it establishes a dissonance with the sense of authenticity presented by Ferrete, Nepomuceno and Sant'Anna, who regard the modernization of caipira music as a loss of its roots and authenticity.

\section{Caipira or serteneja: Ferrete's paradox.}

Throughout his book, Ferrete finds himself confronted with the paradox described by the title "Captain Furtado: caipira or serteneja viola?", which is caused precisely by his discontent with the modernization of caipira music. The author not only criticizes the mixture of caipira music with foreign rhythms and instruments, but imposes on himself the mission of presenting the biography of one of the first musicians to bring to the genre influences from Paraguayan, Uruguayan and Mexican music, as seen in the guarânias, rancheiras and corridos sung by Capitão Furtado. According to Nepomuceno:

[His] dice was (well) tossed. Until the end of his life, without playing an instrument - having only a notion of viola -, he would write, according to his testimony, over a thousand lyrics, having had 350 of them recorded. "Modas de viola”, “maxixes”, waltzes, sambas, "toadas”, “baião”, “congadas”, "galopes”, “arrasta-pés”, fandangos, marches, "forrós”, "guarânias”, "xotes”, "rancheiras', songs, contests, boleros, "dobrados”, “cateretês”, "corridinhos”, "calangos”, "rasqueados", "lundus", "batuques" and mazurcas, were all genres in which he ventured (Nepomuceno 1999: 280-281).

In the chapter "Rural music in Brazil", Ferrete establishes a geographic differentiation between the caipira and serteneja genres. While caipira music would be that created in the South, Southeast and Midwestern regions and equivalent to rural music, serteneja is found in the Brazilian Northeast. He considers the change of nomenclature from serteneja to Northeastern music to be a mistake and cause for confusion among researchers. In addition to geographic differences, traits related to regional cultural backgrounds mark both genres, and the main instruments used by each are different: the caipira viola and the serteneja viola. That is why he states that "the music we will address here is 'caipira". We will address serteneja music on another occasion" 
(Ferrete 1985: 27). Furthermore, his perception of a qualitative difference between caipira and serteneja is due to his understanding that "the 'sertão' as described by Euclides da Cunha is very different from the rural zones of the Brazilian Midwest, Southeast and South, making us see as absurd the lack of distinction made between the inhabitants of the sylva horrida and those who harvest wealthy land" (Ferrete 1985: 26)..

However, Ferrete's statement simply presents a target to be reached, and the serteneja music category is used throughout the book and is given new meaning especially in the last chapter, "From the hick to the mariachi: the trajectory of transformation", where he dedicates himself to presenting a panorama of the changes to rural music in Brazil. Here it is the similarities originated from the process of colonization that allow different rhythms to be recognized by both the inhabitants of the caipira regions and the sertenejas. That is why he states:

In Brazil we have regions of distinct cultural manifestations in an inequality that, however, has points in common that are well defined by trivial means. For example: the accordion. It had always been an instrument characteristic of all Brazilian regions, which was made widely common by the Portuguese over three hundred years of cultural predominance. Certain types of viola... indicate sounds from the North to South of the country in a homogeneous manner, demonstrating unity in certain aspects of the inequality and cohesion in national identity (Ferrete 1985: 117).

In spite of the regional differences that Ferrete indicates to distinguish caipira from serteneja music, he recognizes a set of similarities that provide unity and cohesion to what he calls the versatility of "regional popular music in Brazil" and of Capitão Furtado songs. The different kinds of regional music were marked by the same process of cultural formation, but with a characteristic accent that differentiates them from urban music, which is understood as the music made in the cities of Sao Paulo and Rio de Janeiro. In spite of this versatility, caipira and serteneja songs would not be recognized by their audiences, given that before the records produced by Cornélio Pires these songs were sung by singers not authentically “caipira' or serteneja. Ferrete attributed this to a lack of regional singers, which does not change his perception that it sounded like an imitation or something inauthentic. Capitão Furtado, meanwhile, with all his versatility, was an authentic caipira, given 
that authentic is defined by a series of historical and geographical influences. The author states that "Ariovaldo Pires was not a close 'imitation' of a type which would be a source of fascination. He was the actual type" (Ferrete 1985: 58). In this sense, the great merit of Cornélio Pires and Capitão Furtado was that they brought "authentic 'caipiras", to the music scene by taking the place of artists who only "imitated" rural men.

Ferrete maintains that Capitão Furtado' authenticity is not questioned by the fact that he wrote songs influenced by other Latin rhythms. The success of one of his versions of a Mexican song is seen as "a social attraction to the similar", sympathy for the rural culture of other countries. But the author acknowledges that the success of this song opened the door to a mixing of the caipira and the foreign that would: "lead to another kind of rural song". (p.122). When bringing foreign songs to the rural music made in Brazil, Capitão Furtado submitted them to his own caipira style, a "caipiration" process in which they gained traits of Brazilian rural music.

According to Ferrete's criticism, it was not the simple mixture, but the commercialism - the excess mixture to increase record sales - that transformed rural music. He called the new trend modern sertenej $\alpha^{21}$. This modernization, initiated by Capitão Furtado, found in artists like "Milionário e Zé Rico" a total alienation of the genre (Ferrete 1985: 123) and led to a transformation into a genre that he no longer considered to be rural music. Ferrete criticized the duet "Cascatinha e Inhana" for abusing the use of successful formulas without contributing to a renewal of the genre. After the success of the song Índia"- in a "guarânia" style in a version by Capitão Furtado - the duet contributed for "those without much imagination to attract an audience as consumers, generating seeds of hundreds of sub-products" (Ferrete 1985: 122). To Ferrete, the attachment of many duets to these formulas for success, several of them discovered by Capitão Furtado, led to a stereotype, and what was announced as a "new 'sertaneja' wave" between the 1970s and 1980s was a return to this imitation of the caipira, a fact unknown to the audience. As he asks in the last sentence of his book: "and those who buy it, will they know?"

\footnotetext{
21 The songwriters and performers targeted by Ferrete's criticism are mainly "Milionário and José Rico" and "Trio Parada Dura" and others in the late 196os and throughout the 1970s. Given that his book was written in the early 1980s, he does not write about the romantic "sertanejos" as do Nepomuceno and Sant'Anna. However, his book aims to demonstrate that other qualifications of the caipira and serteneja genres are subject to different perceptions of authenticity.
} 
Capitão Furtado's incursion into other musical genres, in addition to his work in theater and film, caused a discontentment that puzzled Ferrete who questioned his friend. The songwriter's response was that his paths were subject to his "desire to create". The solution to Ferrete's paradox arises from his understanding that all of Capitão Furtado's work as a songwriter, a writer of Brazilian versions of foreign songs and as a text writer was not based on commercialism, but that there was a division between what was "eugenic" - his own will for personal perfection - and what was "inherited from tradition" - his “caipirism". In Ferrete's eyes, the authenticity of Capitão Furtado, his “caipirism" inherited from tradition, was not disturbed by his works motivated by his "eugenic" side, but was actually strengthened by it since it was subject to his creative will.

\section{Sant'Anna, Nepomuceno and the dilemmas of "modernization"}

Although Nepomuceno occasionally mentions in her book that caipira music has its roots in the arrival of the Portuguese to Brazil, and dedicates a chapter to this influence, she basically focuses on the period from the beginning of the recording industry until the 1990s. The subtitle of her book is suggestive of the history she narrates. While Sant'Anna, who only analyzes caipira music that he finds to be linked to a ritual context - although he uses in his work nearly 700 phonographically recorded “caipira' songs -, Nepomuceno prefers to tell the story of the genre "when it leaves the fields" and moves to the big city. She focuses on the moment when Cornélio Pires and his nephew Capitão Furtado begin to disseminate not only the "modas de viola" and other caipira rhythms by means of phonographic recording, but also over the radio and through lectures given to an "urban" and intellectual audience. One can say that she wrote a biography of caipira music made since the 1920 .

Both the first and second part of her book begin with biographical chapters about João Pacífico, a writer of popular caipira songs in the 1930 s and 1950s. Nepomuceno was the last journalist to interview him, and regrets that the songwriter died without public acknowledgement. She compares his life and death to that of serteneja singer Leandro - who created a modern serteneja duet with his brother Leonardo. Both came to Sao Paulo as youngsters: João Pacífico from the coffee plantations while Leandro from the region of vegetable farms in Goiás. Nepomuceno says: 
It happens that João lived too long, almost 90 years. He witnessed all the transformations (from caipira to serteneja music), walked on red carpets, dressed up in linen suits, received homage and, because he lived in a country perhaps too young to understand its old artists, old values and old stories, he died poor and isolated (Nepomuceno 1999: 20).

A few months earlier ... the country was moved by the passing away of Luís José Costa, a.k.a. Leandro, at age 37... a typical representative of a generation of rural youth, eager to adjust themselves to a new profile: that of pop serteneja, blessed by the large recording companies.... Leandro accepted the challenge of large scale success. And in this endeavor, the ten-string viola, the typical instrument of Joao's universe, was forever lost "Entre tapas e beijos" ["Between slaps and kisses"], crushed by tons of equipment and sales of millions of records (Nepomuceno 1999: 21-22).

By comparing João Pacífico to Leandro, the author uses them as metaphors for her history of caipira music. One was the old representative of a genre that would be the expression of the soul of the people, but was not highly valued. The other, a young modern serteneja, whose success - defined by skyscraping sales - was supported by the record industry. The first one died old, having maintained the vitality and joy of living, and was a living witness to the transformations in caipira music. The latter moved the country by his early and painful death, deprived of a long life to enjoy his success.

Pop serteneja (also known as romantic serteneja, modern "sertanejo, or simply serteneja) performed by duets such as "Leandro e Leonardo", "Zezé di Camargo e Luciano" and "João Paulo e Daniel” - which have enjoyed mega success in the recording industry - is considered not only by the author but by many other voices that she brings to the book to confirm her views, to be those genres that led to a maximum loss of the traits of caipira music. Quoting Ferrete, Nepomuceno affirms that these duets gave the genre traits of total alienation, and criticized them similarly to how "Milionário e Zé Rico" and "Cascatinha e Inhana" are criticized in the book on Capitão Furtado.

The similarity of her position to that of Ferrete reveals that at times she agrees and others disagrees with the biographer of Capitão Furtado. For Nepomuceno, rural music lost its purity and accent in the 1950 shen "modas de viola" were mixed with other Latin genres and instruments other than the viola became incorporated. She champions the need to preserve the original 
traits of music from the interior so that it does not vanish. (Nepomuceno 1999: 23). Entrepreneur Beto Carreiro considered the abandonment of the roots of serteneja music to be an evolution, an updating, an adaptation to new sounds. Nepomuceno links this transformation in serteneja music to Brazil's new agrarian structure. The new serteneja would sing to "a Brazil whose countryside was once again enjoying great economic strength, six decades after having gone through the wealthiest period of the coffee plantations"' (Nepomuceno 1999: 201). There was a subtle relationship between the new forms of agricultural production that led to expanded wealth, especially in the Midwest region, and the expanded wealth in the modern serteneja genre. This contributed to the idea that being modern was more attractive than being a modernist, thus a choice was made to modernize caipira music in the modes of U.S. country music. ${ }^{22}$ Finally, the romantic "sertanejos" were addressing a public that could no longer be identified as caipira.

The arrival of the reproduction of the "caipira modas" on record and their radio broadcast represented the first significant change, according to Sant'Anna. These changes fulfilled a cycle of transformation and adaptation to the new times, as happened previously to the medieval novel. In the initial decades of its transformation, "moda caipira" had mainly lost its literary traits, and was transformed into short ballads, as in the modern novel. However, those first modifications have nothing to do with romantic serteneja music, something that he simply ignores in his work. Like Ferrete, Sant'Anna's analysis of the record industry and the transformation of caipira into serteneja focuses exclusively on Young Serteneja Music, represented by "Milionário e José Rico”, “Trio Parada Dura” and, the early career of "Chitãozinho e Xororó". This new genre was not identified with the roots "moda caipira", because its urban face would only have "cultural residuals" and would be closer to the "genre of photo-novels and soap operas of today",

\footnotetext{
22 In O campo na cidade ("The Country in the City"), Gonçalves de Paula acknowledges that the appearance of a country phenomenon in Brazil has a close link to the U.S. cowboy lifestyle. However, he states that those re-creations are inserted in the field of the Aristotelic conception of mimesis and there is no simple reduction at imitatio. For this reason, "it contains transforming elements and even deforming ones regarding that which he takes as a starting point" (Gonçalves de Paula: 9). The most significant difference refers to labor and not to the sophistication found in American country. According to de Paula, opposite to etiquette and refinement, the American cowboy nurtures a certain degree of solitude and isolation in relation to the urban way of life. In Brazil, to the contrary, the country lifestyle is strongly based on urban manners, being close to a rural aesthetic with an urban style.
} 
where life's problems are summarized by the "anxiety of sentimental matters and the alienation and laxity of an impressive repetition of philistine gossip (Sant'Anna 2000: 362). In an analysis based on the works by Caldas, the "cultural remains" found in the young serteneja music - "pieces of culture components" - collaborate with the preservation and stabilization of the existing social-economic structure.

Sant'Anna's nostalgia for roots "moda caipira" has the bitter taste of a time lost to modernization in which each individual is left to survive in a disenchanted world, dominated by mass media, under an ideological control that transforms the population into mere consumers rather than "elaborators of a final discourse". The difference between the modern entertainment industry represented by young serteneja music - and the "free singing" of the caipira - which is subject only to local sociability and the rural context - led to "the large scale loss of interest by new urban generations which, seduced by the voluptuous power of the media and a fascination for predictable electronic effects (kitsch pretending to be luxury), avoid seeing the "caipira moda" within its cultural and esthetic dimension, within its literal dimension" (Sant'Anna 2000: 333). However, Sant'Anna sees a positive element in young serteneja music. By trying to establish a link to roots caipira music it helped publicize the genre throughout Brazil. Thus, the media can play the same pedagogical role as performed by ancient rituals, he affirms.

The ideal of authentic “caipira' music is strongly linked to a notion of ritual context, where all relations are part of a whole and inextricably selfreferent among themselves. This perception guides not only the way the authors studied here understand this, but also the mechanisms they use to qualify and re-qualify the caipira genre as it becomes modern serteneja. Nepomuceno states, in several parts of her book, that the "capira" music brought from the rural zones to the urban centers by Cornélio Pires and Capitão Furtado was not thought to be as commercially feasible as modern serteneja music. It did not have the status it began to be given by a share of the intellectualized elite with the arrival of the new "caipiras". For Nepomuceno, regardless of the prejudice against caipira music, which was not considered art by some, it became financially interesting enough for the record companies to maintain it, as "the music of the poor, of country folk and inhabitants of the periphery, which brought the record labels ever more 
profits. It had its own market niche: the second class, the backyard ${ }^{23}$, the kitchen - after all, it was the music of the hick, well accustomed to toiling the land and making money for the boss to appear elegant in city ballrooms" (Nepomuceno, p. 162).

Thus the caipira portrayed by Nepomuceno, Ferrete and Sant'Anna is in no way similar to those performers who became wealthy with the progress provided by the new communications media and modes of production found in the rural zones of Mato Grosso, Goiás, Sao Paulo etc. Understanding music as a form of expression, Nepomuceno sees in the modern serteneja the reflection of a new agrarian elite that has nothing to do with the caipira known for simplicity, rusticity and cordiality. Such traits explain why romantic "sertanejos" do not like to be seen as "caipiras". They use the wealth gained from the success of their songs to erase the "scars of poverty" that would label them as caipira. While they distance themselves from the "sad and false" image of the Jeca Tatu (hick) created by writer Monteiro Lobato ${ }^{24}$.

In this regard, Sant'Anna and Nepomuceno adopt a similar perspective by seeing the arrival of an agrarian bourgeoisie as contributing to the "flourishing" of Young serteneja Music. But Sant'Anna does not identify an attempt by the "young sertanejos" to distance themselves from their rural past. The advance of the large monoculture crops contributed to the appearance of a new agrarian bourgeoisie, which ended the folkloric and popular celebrations, and which lost their way in the technical and economic environment. The large scale productions would inhibit popular freedom, according to Sant'Anna Young serteneja music stepped in to fulfill a new demand. In other words, caipira music became modified because the ritual caipira context ceased to exist.

The modernization of caipira music and its transformation into serteneja

23 In the same collection in which Da roça ao rodeio ("From the field to the rodeo") was launched, the history of the "choro" musical genre is told, yet has an inverse moment as its starting point, as seen in the title of the book: Choro: do quintal ao Municipal.("Choro: from the backyard to the Opera House"). It affirms that in the history of samba, the idea of its marginalization compared to other genres with European origin is recurrent. There has been a constant discourse about the marginalization of Brazilian music. All genres - from samba to caipira, including bossa nova and Brazilian rock - have suffered "prejudice", either from part of the intellectualized elite or from the market. In the case of rock music, the difference is that marginalization is seen as desirable, since it grants authenticity. See Freire F, 2003.

24 The image of the squatting, moody and brooding, "caipira man" created by writer Monteiro Lobato through his character Jeca Tatu is rejected by most authors, who try to emphasize the joyful, keen and extremely well informed caipira. For Nepomuceno, Sant'Anna and Ferrete, the figure of Jeca was responsible for part of the urban prejudice surrounding the caipira and his way of life. 
music is also seen as a process opposite to that of Brazilian modernism, which is understood as an "anthropophagic environment where the country would discover itself as being beautiful and multifold" (Nepomuceno 1999: 109). The anthropophagus behavior described by the Brazilian modernist artist Oswald de Andrade along with the interest of Mario de Andrade in national folklore are appropriated in this narrative as examples of an attitude interested in all things national and in a new understanding of Brazilian cultural diversity. The main attitude in modern Brazil would be the search for what is international, with the adoption of new languages and technologies that would bring the modern serteneja closer to U.S. country music than to Brazilian caipira.

Inezita Barroso, an upper middle class carioca who became interested in caipira music is analyzed by Nepomuceno as an example of this modernist attitude. The modernist project of Mario and Oswald de Andrade became a model for the discourses on authentic caipira music and the appropriation of this proposal became essential to a certain perception about national culture and identity, with a harmonized internal diversity, to which the caipira way of life would be integrated.

Proving that being modern meant to respect the past, she [Inezita] would reign on the scene, promoting a Brazil that she had learned to love in her childhood, having Mario de Andrade and Raul Torres as idols - a country that used to be proud of its origins, of its music, of its culture... (Nepomuceno 1999: 151).

The modernist attitude of Inezita Barroso is also translated into an acceptance of caipira music - which, according to Nepomuceno, was always regarded with prejudice by a certain intellectual elite. Thus, one notices a constant attempt by the author to demonstrate that Brazilian popular music is widely impregnated by "rural symbols" (Nepomuceno, p. 115). She points out how rural music penetrated popular music styles that are given an elite treatment, as in the case of bossa nova. This can be seen in recordings of music considered caipira by singers such as Elis Regina, Rita Lee and Milton Nascimento, and in the genre's influence on composers such as Tavinho Moura and musicians like Rogério Duprat. In all of them a modernist attitude is recognized, in the sense that caipira music is used in an anthropophagic manner and receives new arrangements.

"The posture of wanting to be modern, letting go of popular traditions," is for 
Sant'Anna something that does not combine with the search of Brazilian and European intellectuals for a popular culture to serve as a basis for developing a national identity with a modern sense of self. It is in modernity, he affirms, that the process of massification - which alters all values related to popular cultures - becomes effective. The desire to be modern is part of this modernity where the elite converts the culture of the people into a culture for the people. The sense of inferiority caused by authentic culture is linked to the history of segregation of blacks and indigenous Brazilians and would find an answer in the adoption of elements of their culture by part of the elite. Thus modernity is the instauration of a "model marked by the logics of neo-liberal authoritarianism and linked to mercantilist greed...” (Sant'Anna 2000: 350).

Sant'Anna locates the "moda caipira" among the cultivated arts, where it is considered a "legitimate representative of a cultured layer of the Brazilian songbook". That is why he disagrees with the position of the so called cultural elite that does not see artistic traits in "moda caipira." He tries to place it within a context of the fine arts. Thus he states:

Since the early days, from the first 52 78rpm recordings made by Cornélio Pires for the Columbia label between 1929 and 1931, roots "moda caipira" shows the occurrence of procedures common to a poetry considered "literate", erudite. (Sant'Anna 2000: 347 ).

As in Mario de Andrade's modernist project - Sant'Anna proposes to find in the folklore the raw material for a genuinely Brazilian art - an "enlightened art" that is an "overcoming of what is popular" yet never a rupture" (Sant'Anna 2000: 77). Thus, by understanding that "moda caipira" belongs to a context of illustrated culture, Sant'Anna is less in favor of its approximation to mass culture and suggests it should have a place of its own in the field of arts.

Sant'Anna is not able to escape presenting a scheme in which popular culture is inferior to erudite culture and he contributes little to overcoming this antinomy. Likewise, in an attempt to overcome the erudite-popular antinomy, Nepomuceno also winds up emphasizing instead of overcoming the establishment of an erudite-popular antimony. Because they use viola arrangements and other traits of caipira music in their music, she considers artists such as Rogério Duprat, Rita Lee and Jorge Benjor to have re-introduced the genre to the musical scenario through the front door. Renato de 
Andrade, ${ }^{25}$ for instance, began to use the viola as a chamber instrument, and gave it a new status. It is clear that the antinomies erudite-popular, high-low culture are not overcome. To the contrary, both Sant'Anna and Nepomuceno, speak of an "eruditization" or "elitization" of the genre.

Nepomuceno quotes historian Antônio Carlos Tonca Falseti: '"caipira' music was the last trench to be won by the imperialist cultural industry, which had exported to us several musical genres" (A. C. Tonca Falseti apud Nepomuceno: 203). ${ }^{26}$ The idea of caipira music as the last form of resistance to American cultural imperialism - linked to economic imperialism - is a recurrent theme, and it also counters the modernist values promoted by the author, who sees in popular traditions the means needed to resist the globalization of culture ${ }^{27}$. That is why actor, singer and former TV broadcaster Rolando Boldrim would not allow singer Sérgio Reis on his show Som Brasil, given that Reis wore an American cowboy hat. Boldrim told Nepomuceno:

I would invite everyone, as long as they didn't sing hits, but roots music; "modas", "cateretês", and ask them to come naturally dressed, without show attire. To modernize is not the same as getting American music and copying the arrangements or to put Portuguese lyrics to Mexican music. We have to modernize what is ours (Rolando Boldrin, apud Nepomuceno 1999: 23).

Modernization is understood, in the critical discourse, as part of a new colonization carried out by U.S. culture. However, the process was different from that of Portuguese colonization - which by populating the country led to the appearance of a new nation and of "caipirism" itself - U.S. colonization only replaced the values of the caipira music and way of life without offering

25 Renato de Andrade was not the first musician to use the viola to play chamber music. See Nepomuceno (1999), nota 1, p. 178.

26 Sant'Anna also shares this understanding and states that: "for the opressed, the "moda caipira", the caipira art is a concrete opportunity for emancipation" (Sant'Anna 2000: 116).

27 In 'O 'Pessimismo sentimental' Sahlins (1997) remarks that the U.S. concept of culture began to dissolve in Brazil the very moment it seemed to become dominant. He challenges this feeling" by proposing that the study of culture must not be mistaken with an attempt to save "cultures" (or social orders) that, in theory, are being lost. This way, neither the concept of culture nor the so called primitive peoples that anthropology has addressed would have suffered such a threat, since neither the concept of culture nor the peoples themselves are paralyzed or immutable objects. Culture is more than the reflection of a mode of production and encompasses a world system, a form of social organization. Therefore it is only possible to understand culture based on the contexts where values and meanings are constantly elaborated and re-elaborated by cross-cultural actions. Sahlins' proposals challenge the perspectives of accommodation /adaptation versus resistance. 
any exchange. Thus, according to Nepomuceno and Sant'Anna, the new U.S. vessel would navigate throughout the mass media enjoying mass promotion on TV. This is a recurring argument used by Nepomuceno and other protagonists in her book to explain the lack of space on TV and radio for caipira programs and for the caipira genre itself. Being in the media, according to Nepomuceno, implies participating in an intricate system of ideological control, which would not allow the public to discriminate between caipira - both the way of life as well as the music - and modern serteneja.

For Sant'Anna, the narratives of the "caipira modas" evoke the life not only of the singer/songwriter but include things he heard. A singer attributes feelings and sensations to the narrated interpreter/character, merging both in a single figure. In this sense, there is a meta-fiction, in which singer, character and listener mingle. The narratives of the critics of modern serteneja music use the same procedure. All of the authors qualify themselves as caipira and emphasize the role of their own experiences as a basis for the desire to speak about the theme. So they are all linked to the ritual context they describe, just as the producer and consumer of caipira music are inseparable.

The strength of this indissociation is revealed in the account of the authenticity of the caipira music genre compared to modern serteneja. In these narratives, the caipira and serteneja genres have a metonymical relation with songwriters, producers, musicians, viola players, singers and duets, in which talking about oneself is to also talk about the other. Therefore when they say a genre is authentic compared to another considered inauthentic, what is at stake is the preservation of the artist's authenticity.

From a Freudian perspective, the discontent comes from the ambivalent feelings of the subjects - individual and collective - regarding the passage from a state of nature to a state of culture or, even resulting from the selfother relation. The civilization process - where natural or childish human instincts are subject to social control - would never be complete and individuals would always be submitted to the gap between the natural world and the social world (Freud, 1987). This perspective becomes particularly interesting when trying to understand the narratives of the journalists analyzed here. Far from being incoherent, their arguments are not simple and reveal ambivalent feelings: if on one hand they perceive a gradual abandonment of the roots of caipira music, on the other hand they understand that this process gives to it a permanence in the popular songbook. 


\section{Bibliography}

BENJAMIN, Walter. 1980. "A obra de arte na época de suas técnicas de reprodução". In: W. Benjamim; M. Horkheimer; T. W. Adorno; J. Habermas. Textos escolhidos - Os Pensadores. São Paulo: Ed. Abril. pp. 3-28.

BERLIN, Isaiah. 2000. The proper study of mankind: an anthology of essays. New York: Farrar, Straus and Giroux.

BOURDIEU, Pierre. 1996. As regras da arte: gênese e estrutura no campo literário. São Paulo: Cia. das Letras.

CALDAS, Waldenyr. 1979. Acorde na aurora: música serteneja e indústria cultural. 2 a ed. São Paulo: Editora Nacional.

CÂNDIDO, Antônio. 2001. Os parceiros do Rio Bonito: estudo sobre o caipira paulista e a transformação dos seus meios de vida. São Paulo: Editora 34. CAVALCANTI, Maria Laura Viveiros de Castro. 2004. "Cultura popular e sensibilidade romântica: as danças dramáticas de Mário de Andrade”. Revista Brasileira de Ciências Sociais, 19(54): 57-79.

CAZES, Henrique. 1998. Choro: do quintal ao Municipal. São Paulo: Editora 34. DAMATTA, Roberto. 1984. Relativizando: uma introdução à antropologia social. Petrópolis: Editora Vozes.

FERRETE, João Luís. 1985. Capitão Furtado: viola caipira ou serteneja. Rio de Janeiro: Funarte.

FREIRE FILHO, João. 2003. "Música, identidade e política na sociedade do espetáculo". Interseções. Revista de Estudos Interdisciplinares, 2: 303-327.

FREUD, Sigmund. 1997. O mal-estar na civilização. Rio de Janeiro: Editora Imago.

GONÇALVES DE PAULA, Silvana. 1999. O campo na cidade - esportes country e ruralidade estetizada. Tese de Doutorado, Instituto Universitário de Pesquisas do Rio de Janeiro, Universidade Cândido Mendes — Rio de Janeiro.

GONÇALVES, José Reginaldo Santos. 1988. “Autenticidade, memória e ideologias nacionais: o problema dos patrimônios culturais”. Estudos Históricos, 2: 264-275.

GONÇALVES, José Reginaldo Santos. 1996. A retórica da perda: os discursos do patrimônio cultural no Brasil. Rio de Janeiro: Editora UFRJ/IPHAN.

MARTINS, José de Souza. 1975. "Música 'sertaneja': a dissimulação na linguagem dos humilhados". In: Capitalismo e tradicionalismo: estudos sobre 
as contradições da sociedade agrária no Brasil. São Paulo: Pioneira. pp. 103-161. MORAES, Eduardo Jardim de. 1999. Limites do moderno: o pensamento estético de Mário de Andrade. Rio de Janeiro: Relume Dumará.

NAVES, Santuza de Castro. 1998. O violão azul: modernismo e música popular. Rio de Janeiro: Editora Fundação Getulio Vargas.

NAVES, Santuza de Castro. 2001. "A canção crítica”. In: C. N. Matos; F. T. Medeiros; E. Travassos (orgs.), Ao encontro da palavra cantada: poesia, música e voz. Rio de Janeiro: Editora 7 Letras. pp. 289-298.

NEPOMUCENo, Rosa. 1999. Música caipira: da roça ao rodeio. São Paulo: Editora 34.

SAHLINS, Marshall. 1997. “O 'pessimismo sentimental' e a experiência etnográfica: porque a cultura não é um 'objeto’ em via de extinção” (partes I e II). Revista Mana. Estudos de Antropologia Social, 3(1-2): 41-73; 103-150. SANDRONI, Carlos. 2000. Feitiço decente: transformações do samba no Rio de Janeiro (1917-1933). Rio de Janeiro: Jorge Zahar Editor/ Editora UFRJ.

SANT'ANNA, Romildo. 200o. A moda é viola: ensaio do cantar caipira. São Paulo: Editora Arte \& Ciência.

SANTOS, Elizete Ignácio dos. 2005. Música caipira e música serteneja: classificações e discursos sobre autenticidades na perspectiva de críticos e artistas. Dissertação de Mestrado, Instituto de Filosofia e Ciências Sociais, Programa de Pós-Graduação em Sociologia e Antropologia, Universidade Federal do Rio de Janeiro - Rio de Janeiro.

SAPIR, Eduard. 1949. “Cultura 'autêntica' e 'espúria”. In: D. Pierson (org.), Estudos de organização social: leituras de sociologia e antropologia social. São Paulo: Livraria Martins Editora. pp. 282-311.

SOUZA, Eneida Maria de. 2002 "O discurso crítico brasileiro”. In: Crítica cult. Belo Horizonte: Editora UFMG. pp. 47-66.

STOCKING, George W. 1989. "The ethnographic sensibility of the 1920 and the dualism of the anthropological tradition”. In: Romantic motives: essays on anthropological sensibility. Madison: The University of Winsconsin Press. pp. 208-279.

TINHORÃO, José Ramos. 1974. “Os gêneros rurais urbanizados” In: Pequena história da música popular: da modinha à canção de protesto. Petrópolis: Vozes. pp. 185-205.

TINHORÃo, José Ramos. 2001. “Música 'sertaneja' é esse negócio”. In: Cultura popular: temas e questões. São Paulo: Editora 34. pp. 205-212. 
TRAVASSOS, Elizabeth. 1997. Os mandarins milagrosos: arte e etnografia em Mário de Andrade e Béla Bartók. Rio de Janeiro: Funarte/Jorge Zahar Editor. TRILLING, Lionel. 1972. Sincerity and authenticity. Cambridge: Havard University Press.

\section{About the author}

Elizete Ignácio dos Santos

Master and Doctoral Candidate at the Sociology and Anthropology Graduate program of the Federal University at Rio de Janeiro.

Project Management Technician at Cultural Association Friends of Edison Carneiro Folklore Museum.

\section{Main Publications}

CASTRO, O.; FAVARETO, A.; SANTOS, E.; LEMOS, R.; MENEZES, M.; SIMAS, M.; TOSTA, A.; ABRAMOVAY, R. 2008. Tecnobrega: O Pará Reinventando o Negócio da Música. Rio de Janeiro: Aeroplano.

SANTOS, E. 2008. "Dom e Autenticidade : análise sobre duas categorias usadas na definição do artista”. In: Giumbelli, E. Naves, S. Diniz, J. (Orgs.). Leitura sobre a música popular:reflexões sobre sonoridade e cultura. 1 ed. Rio de Janeiro: Sete Letras.

SANTOS, E.; VELOSO, L. 2009. "Consumo e Sociabilidade na Construção do Imaginário Carioca”. In: Portilho, F. Veloso, L, Barbosa, L. (Org.). Consumo: Cosmologias e Sociabilidade. Rio de Janeiro. Seropédica: Mauad X; EDUR. SANTOS, E. 2009 . “Algumas abordagens sobre o conceito de Cultura”. In: Curvelo, M. A.; Frade, C.; Calabre, L. Nacif, R. Lima, R. (Orgs.). Políticas Públicas de Cultura do Estado do Rio de Janeiro: 2007-2008, 2009. Rio de Janeiro: UERJ/Decult. 